\title{
UNSUR-UNSUR LINGUAL DALAM WACANA WIFIQ
}

\author{
Muhammad Nanang Qosim \\ nanang_qosim86@yahoo.com \\ Universitas Padjadjaran
}

\begin{abstract}
Abstrak
Penelitian ini membahas tentang unsur-unsur lingual dalam struktur wacana wifiq. Wacana wifiq merupakan bagian dari ragam bahasa tulis. Metode yang digunakan dalam penelitian ini menggunkan deskriptif analisis dengan teknik pilah unsur dan teknik sigi. Sumber data menggunakan buku Al-Aufaq Karya Imam Al Ghazali. Hasil penelitian menunjukkan adanya unsur-unsur lingual dalam struktur wacana wifiq sebagai pembentukkan wacana wifiq, yaitu unsur huruf, unsur kata, unsur teks, unsur simbol, unsur gambar dan unsur angka.
\end{abstract}

\section{Kata-kata Kunci: Unsur, Lingual, Wifiq, Wacana}

\section{PENDAHULUAN}

Lambang bahasa adalah lambang bunyi. Hal ini berarti bahwa sifat bahasa memanfaatkan varian bunyi yang diucapkan dan didengar. Maka tulisan merupakan upaya untuk mengungkapkan bahasa dalam realita bunyi. Tulisan merupakan upaya untuk mengalihkan fenomena bunyi yang dapat didengar ke fenomena tulisan yang dapat dilihat (Jinni, 1957: 1).

Tulisan merupakan upaya untuk menerjemahkan fenomena bunyi yang didengar ke dalam fenomena tulisan yang dilihat serta tulisan merupakan upaya mengalihkan bahasa dari dimensi waktu ke dimensi tempat. Sejalan dengan pendapat Al Ghazali dalam Buhairi (2005: 139) bahwa sesuatu itu memiliki wujud nyata, wujud pada lisan, dan wujud pada ide, sedangkan wujud nyata adalah wujud asli, sementara wujud ide adalah wujud ilmiah. Dijelaskan Ikhwan As Safa dalam Buhairi (2005: 139) wujud ide disebut sebagai huruf-huruf ide ('al hurūf 'l-fikriyyah) dalam hal ini Ikhwan As Shafa membagi huruf menjadi ide (fikriyyah), lafal (lafziyyah), dan tulis (khattiyyah). Ulama klasik dan modern mendiskusikan wujud tulisan, yaitu berdasarkan pendapat Ibnu Khaldun dalam muqaddimah bahwa tulisan adalah bentuk perpindahan darinya kepada makna yang ditunjuk (intiq $\bar{a} ' l$ minhā ilā mā tusyīru 'ilaihi min ma'ānin). Keberadaan tulisan (khatt) bersifat sekunder di samping keberadaan lafal. Huruf-huruf tulis tersebut menjadi tanda bagi huruf lisan dan huruf lisan menjadi simbol dari huruf ide (huruf asli) (Buhairi, 2005: 139).

Sehubungan dengan bahasa tulis, wacana wifiq merupakan bagian dari ragam bahasa tulis. Berkaitan dengan pemahaman mengenai wacana menurut Kridalaksana (2008: 259) bersandarkan pada Haris, Pike, yaitu satuan bahasa terlengkap dalam hirarki gramatikal merupakan satuan gramatikal tertinggi atau terbesar. Wacana direalisasikan dalam bentuk karangan yang utuh (novel, buku, seri ensiklopedia, dsb), paragraf, kalimat, atau kata yang membawa amanat yang lengkap. Wacana merupakan tataran paling tinggi dalam hirarki kebahasaan 
dan bukanlah kumpulan kalimat secara acak, tetapi kesatuan makna yang terletak secara berkesinambungan dan membentuk satu kesatuan yang padu dan utuh (Halliday dan Hasan 1979, Djajasudarma, 2012: 3). Pada dasarnya wacana menekankan bahwa satuan bahasa terlengkap, tertinggi, atau terbesar di atas kalimat atau klausa dengan kohesi dan koherensi tinggi yang berkesinambungan serta mempunyai awal dan akhir yang nyata disampaikan secara lisan dan tertulis. Sebagai satuan bahasa yang terlengkap dalam wacana itu terdapat konsep, gagasan, pikiran, atau ide yang utuh, yang bisa dipahami oleh pembaca (dalam wacana tulis) atau pendengar (dalam wacana lisan), tanpa keraguan apa pun.

Sedangkan, wifiq berasal dari kata wafaqun atau wifqun (وفق) yang berarti 'kesepakatan, keharmonisan, atau kesesuaian' (Muhdlor, 1999: 2030). Hanafi (1992: 1) menjelaskan wifiq berkaitan dengan 'ilmu 'asrāru ' $l$ hurūf, yaitu ilmu yang mempelajari tentang rahasia sebuah huruf, seperti bentuk, karakter, dan gambar yang ditulis. Wifiq dikonstruksikan untuk memuat cara komunikasi dalam hubungan transaksional antara manusia dan Allah. Dalam hubungan tersebut, huruf, kata dirangkai, disusun, dan dikemukakan untuk mengungkapkan maksud tertentu, baik bersifat sederhana maupun bersifat kompleks. Wifiq berkaitan dengan bahasa spiritual, artinya bahasa dibuat untuk kepentingan transaksi manusia dan Allah.

Davies (2009: 67) menjelaskan bahwa wifiq merupakan salah satu budaya sastra yang diabadikan sebagai bentuk pengetahuan magis secara tertulis dan lisan yang isinya tentang ilmu pengetahuan. Pada masa lalu tulisan-tulisan yang berkaitan dengan wifiq sangat dirahasiakan bahkan hanya orang-orang tertentu yang dapat memahami dan mempelajari tulisantulisan wifiq atau ujaran-ujarannya. Menurut Loekman (2010: ii), wifiq sebagai wujud kebendaan yang di dalamnya memiliki unsur magis yang mengandung dua dimensi, yaitu (1) intra-estetik yang dapat terindera dan dapat dinikmati secara visual, yaitu berbentuk benda sebagai media penghubung transendental bagi manusia untuk memanjatkan doa kepada sang Pencipta, dan (2) ekstra-estetik, yaitu unsur mistis dan magis yang esensinya berupa kepercayaan dan kekuatan di luar kemampuan manusia. Gardiner (2012) memiliki sudut pandang yang lain tentang wifiq, yaitu dengan kajian filologi bahwa wifiq merupakan 'ilmu hurüf wa'l-aufāq yang artinya tentang huruf dan sebuah kecocokan angkaangka.

Wacana wifiq merupakan satuan bahasa yang tertinggi yang isinya bersifat esoterik, baik secara tulis maupun lisan. Esoterik dalam kamus bahasa Indonesia artinya bersifat khusus (rahasia, terbatas) (Sugono et al. 2008: 401). Sebenarnya istilah esoterik dalam linguistik sudah dikenalkan oleh Thurston (1987) seorang ahli antropolinguistik dalam kaitannya dengan komunikasi esoteris. Komunikasi esoterik merupakan sebuah komunikasi yang dibangun oleh orangorang tertentu dan tingkat sosial yang sama (Thurston, 1989: 556). Sifat esoterik dalam wacana wifiq merupakan wujud sebuah fungsi bahasa yang ditulis atau dituturkan oleh pengguna bahasa.

Sebagai contoh wacana wifiq menggunakan ayat Alquran surat Al Jum 'ah ayat 11 untuk melariskan barang dagangan.

IWa iża ra'ā̄ tijāratan au lahwan 'infaḍ̄ 'ilaihā wa tarakūka qā'imān qul mā 'inda 'l-lāhi khairu mina 'l- 
lahwi wa mina 't-tijārati wa 'l-lāhu khairu 'r-rāziqīn/

"Dan apabila mereka melihat perniagaan atau permainan, mereka bubar untuk menuju kepadanya dan mereka tinggalkan kamu sedang berdiri (berkhotbah). Katakanlah: "Apa yang di sisi Allah lebih baik daripada permainan dan perniagaan", dan Allah Sebaik-baik pemberi rezki" (Q.S Al Jum'ah 11)

Ayat tersebut ditulis di atas kertas lalu diletakkan di tempat dagangan maka muncul pertanyaan mengapa ayat itu yang digunakan, sebagai pembuatan wifiq penglarisan? Ditinjau dari tafsir pragmatik esoteris, penggunaan ayat tersebut karena ada kata /tijāratan/ "perdagangan" serta dilanjutkan dengan pernyataan /wa ' $l$ llāhu khairu 'r-rāaiqīn/ "dan Allah sebaik-baik pemberi rezeki”. Kata /tijāratan/ "perdagangan" sebagai wujud esoteris pada wacana wifiq, kaitan dengan konteks penggunaan ayat tersebut sebagai wifiq penglarisan. Pada ayat tersebut tidak ada hubungan leksikal atau gramatikal yang merujuk pada kata "penglaris" tetapi adanya relevansi penggunaan ayat tersebut sebagai wifiq penglaris.

Berdasarkan wujudnya contoh wifiq di atas merupakan jenis wacana wifiq menggunakan ayat Alquran yang ditulis di atas kertas sebagai media penulisan. Penggunaan ayat tersebut sebagai salah satu media komunikasi antar manusia dan Tuhan. Sejalan dengan Djajasudarma (2012: 5) mengatakan jenis wacana dapat dikaji dari segi eksistensinya atau realitasnya, cara pemaparan, dan jenis pemakaian. Menurut realitasnya contoh wifiq tersebut merupakan bagian dari media komunikasi berwujud tuturan tulis. Realitas wacana dalam hal ini adalah eksistensi wacana yang berupa tuturan tulis. Rangkaian kebahasaan tuturan tulis wifiq dengan kelengkapan bahasa mengacu pada bahasa apa adanya. Pemakaian ayat Alquran sebagai bentuk wacana wifiq bersifat transaksional. Komposisi atau konstruksi contoh wifiq menggunakan untaian ayat ke-11 surat Al Jum'ah. Hal ini sejalan dengan Djajasudarma (2012: 17) untaian kalimat dapat membentuk untaian wacana yang padu. Komposisi merupakan bentuk pengungkapan gagasan berupa gubahan-gubahan yang tercermin dalam susunan berupa kalimat. Wujud kompisisi dapat berupa paragraf, bahkan sampai naskah, dan satu untaian kalimat atau rangkaian kalimat (Djajasudarma, 2012: 17).

Selanjutnya, secara pragmatik budaya mempelajari bahasa yang lebih luas, penggunaan bahasa dalam konteks kultural, sosial, dan psikologis (Djajasudarma, 2012: 77). Contoh wifiq (1) berdasarkan konteks kultural, sosial, dan psikologis digunakan sebagai bagian media interaksi manusia antara manusia dan Tuhan untuk mendapatkan rezeki yang banyak kemudian disebut sebagai "wifiq penglarisan". Memahami contoh wifiq (1) ditinjau dari aspekaspek tuturan yang ditawarkan Leech (1983: 13-15) yang berupa (1) aspek penutur dan lawan tutur, (2) konteks tuturan, (3) tujuan tuturan, (4) tuturan sebagai tindak tutur, dan (5) tuturan sebagai produk tindak verbal.

Pertama, aspek penutur dan lawan tutur, yaitu penutur adalah orang yang menyatakan fungsi pragmatis tertentu dalam komunikasi, sedangkan mitra tutur adalah mitra tutur yang menjadi sasaran dalam berkomunikasi. Berkaitan dengan wacana wifiq penutur adalah manusia, mitra tutur adalah Tuhan dan wifiq yang ditulis sebagai fungsi pragmatis. Kedua, konteks tuturan, yaitu sebagai jalan untuk memahami sebuah tuturan berkaitan dengan konteksnya. Berkaitan dengan 
contoh wifiq (1) penggunaan ayat ke-11 surat Al Jum 'ah berkaitan dengan konteks perekonomian secara khusus berkaitan dengan perdagangan. Secara leksikal atau kata pada contoh wifiq (1) tidak terdapat kata "penglarisan" tetapi adanya relevansi penggunaan ayat tersebut sebagai konstruksi "wifiq penglarisan", hal ini sejalan dengan teori relevansi walaupun relevansi bersifat relatif tapi dapat memberikan makna pada pengguna bahasa. Secara konsep makna penggunaan ayat tersebut sebagai "wifiq penglarisan" merujuk pada segi tiga Richard \& Odgen dalam Parera (2004: 29), yaitu simbol, reference, dan referent. Manusia sebagai reference, ayat sebagai simbol, dan fungsi ayat sebagai referent. Hubungan antara reference dan referent yang dinyatakan lewat ayat Alquran. Ayat Alquran sebagai simbol bahasa dan rujukan atau referent tidak mempunyai hubungan langsung tetapi menekankan hubungan langsung antara reference dengan referent yang ada dalam dunia luar (Qosim, 2014: 16). Artinya penggunaan ayat pada contoh wifiq (1) menjadi bermakna sebagai fungsi "wifiq penglaris" berdasarkan acuannya. Pemahaman penggunaan ayat yang digunakan atau ayat yang dipilih sebagai bagian media komunikasi untuk menyampaikan sebuah harapan. Ketiga, tujuan tuturan adalah apa yang ingin dicapai penutur dengan melakukan tindakan bertutur. Penggunaan contoh wifiq (1) bertujuan sebagai bagian komunikasi manusia dan Tuhan supaya diberi "penglaris" dalam perniagaan. Keempat, tuturan sebagai bentuk tindakan. Pada contoh wifiq (1) sebagai "wifiq penglaris" yang ditulis di atas media kertas disimpan pada tempat perniagaan. Kelima, tuturan sebagai produk tindak verbal, pada contoh wifiq (1) merupakan ayat Alquran yang ditulis di atas media kertas sebagai bentuk ekspresi komunikasi antara manusia dan Tuhan. Pemakaian dari makna pada ayat tersebut sebagai wifiq penglarisan ditinjau dari teori pemakaian dari makna Wittgestein (1983) yang menyatakan makna sebuah ujaran ditentukan oleh pemakaiannya dalam hidup (Wittgestein, 1983, Parera, 2004, Kaelan, 2009).

Berdasarkan uraian di atas serta data yang ditampilkan, penggunaan ayat Alquran sebagai pembuatan wacana wifiq memberikan peluang untuk dikaji berkaitan dengan wacana wifiq dengan kajian struktur. Kajian struktur wacana wifiq melihat unsur lingual pada wacana wifiq.

Tulisan ini bertujuan untuk mengetahui unsur lingual pada wacana wifiq.

\section{METODE PENELITIAN}

Metode yang digunakan dalam tulisan ini adalah metode deskriptif analisis. Metode ini mendeskripsikan data serta hubungannya dengan fenomena yang diteliti. Teknik yang digunakan menggunakan teknik pilah unsur, yaitu dengan memilah unsur lingual dan teknik sigi, yaitu teknik untuk menelusuri unsur-unsur lingual yang terdapat pada wacana wifiq. Dengan demikian, hasil yang diperoleh berupa paparan data yang mendeskripsikan tentang unsur-unsur lingual yang terdapat pada wacana wifiq.

Sumber data yang digunakan buku Al Aufaq karya Imam Al Ghazali yang diterbitkan Toha Putera Semarang tanpa tahun, data diambil 1 buah wifiq yang memiliki berbagai unsur lingual yang mewakili unsur-unsur lingual pada wifiq yang lain. Setelah pemilihan data, data dianalisis dan akhirnya ditarik kesimpulan. 
HASIL DAN PEMBAHASAN

Sajian Data

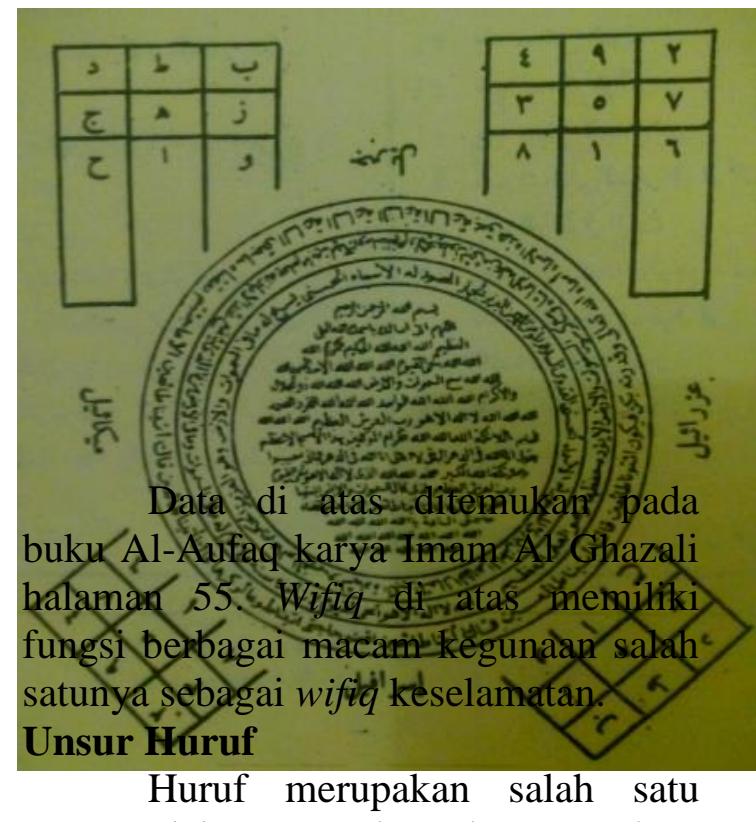

unsur dalam pembentukan struktur wacana wifiq. Huruf-huruf dibentuk atau ditulis berdasarkan ekspresi dan gagasan pikiran manusia pada hal ini penulis wifiq. Wacana wifiq pada dasarnya menggunakan huruf Arab yang berjumlah 28 huruf yang disebut dengan huruf abjadiyah.

Penggunaan huruf Arab dalam pembuatan wifiq merupakan sarana penyikapan spiritual. Ibnu Arabi menjelaskan tentang 28 huruf Arab yang berhubungan dengan perubahan bunyi azali (primordial sound) yang merupakan penyingkapan spiritual dalam bahasa ucapan. Karena hal inilah esoterisme Islam membentuk persesuaian antara 28 tempat bulan dan 28 huruf atau bunyi bahasa suci. Ibnu Arabi juga menyatakan tempat-tempat bulan mewakili model-model huruf, 28 bunyi inilah yang menentukan tempattempat bulan. Bunyi-bunyi huruf pada kenyataannya mewakili ekspresi manusia dan mikrokosmis penentuanpenentuan ynag esensi dari nafas Tuhan yang merupakan motivasi utama siklussiklus kosmis. Ibnu Arabi menghitung 28 bunyi huruf Arab dari tempat bulan pertama yang mengikuti Equinox musim semi dalam tatanan berurutan eksteriorisasi fonetik mereka yang dimulai dengan hiatus (peralihan di antara dua monoftong yang berdampingan yang membentuk dua suku yang berurutan tanpa jeda atau konsonan antara) atau ruang kosong ( $a l$ hamzah) dan terus melalui gutteral (suara tekak yang dihasilkan dalam tenggorokan) ke konsonan labial melewati palatal dan dental. Serangkaian tersebut jika dihibungkan dengan tempat-tempat bulan dimulai dengan ha dan diakhiri dengan wau, huruf tersebut menyusun nama Tuhan Huwa "Dia" simbol satu esensi dan sama dengan esensi (Yang Esa) itu sendiri.

Sebagai persesuaian dalam pembentukan wifiq menggunakan huruf abjadiyah didasari dengan pemahaman astrologis dan persesuaian bunyi huruf Arab.

\section{Unsur Kata}

Penggunaan kata dalam wacana wifiq tidak terlepas dari sifat-sifat Allah dan nama-nama malaikat, dan nabi dari situlah penulis membaginya menjadi dua hal, yaitu nama diri dan kata sifat.

\section{a. Nama Diri}

Penggunaan nama diri sebagai salah satu unsur lingual dalam wacana wifiq menggunakan menggunakan namanama Allah, Malaikat, dan Nabi, yaitu seperti Allah, Izrail, Israfil, Mikail, dan Jibril dan nabi Muhammad saw.

\section{b. Kata Sifat}

Kata sifat dalam penggunaan wacana wifiq menggunakan sifat-sifat Allah ( $A l$ 'Asma Al Husna), di sini dipilih menggunakan kata sifat dari pada nama Allah mempertimbangkan tentang keesaan Allah itu sendiri, sehingga lebih codong pada sifat Allah dari namanama Allah. 
Penggunaan sifat-sifat Allah dalam pembuatan wifiq merupakan sebagai bentuk pujian kepada Allah.

\section{Unsur Teks}

Teks wacana wifiq dari Alquran adalah wacana wifiq yang isinya mengambil dari Alquran berupa surat Alquran, ayat Alquran dan penggalan ayat Alquran serta teks bukan Alquran.

\section{a. Teks Alquran}

Teks Alquran yang digunakan dalam pembuatan wifiq berasal dari surat-surat atau ayat-ayat tertentu yang menjadi pilihan dalam pembuatan wifiq. dari segi pilihan surat atau ayat ditulis secara menyeluruh, penggalan ataupun gabungan.

\section{b. Teks bukan Alquran}

Wacana wifiq bukan Alquran adalah sebuah wacana wifiq yang isinya bukan dari Alquran yang berupa tentang doa-doa.

\section{Unsur Simbol}

Simbol dalam wacana wifiq merupakan bagian dari unsur pembentukan wacana wifiq dalam artian bagian dari struktur wacana wifiq. Walaupun huruf sebagai simbol bahasa pada dalam perspektif secara umum simbol selain huruf digunakan sebagai pembentukkan wacana wifiq. berdasarkan sejarahnya simbol yang digunakan merupakan bagian dari huruf-huruf.

\section{Unsur Gambar}

Gambar merupakan deskripsi sebuah realitas yang adalah unsur bagian dari wacana wifiq. ilustrasi dari sebuah realitas digambarkan atau dilukiskan menggunakan huruf-huruf tertentu yang mempersepsikan tentang sebuah kondisi nyata.

\section{Unsur Angka}

Unsur angka dari segi historis merupakan dari huruf-huruf hindi akan tetapi pada realita sekarang huruf-huruf tersebut berubah menjadi yang dikenal dengan angka. Dari setiap angka tersebut mewakili huruf tertentu.

\section{SIMPULAN}

Berdasarkan pembahasan di atas, terdapat unsur-unsur lingual pada wacana wifiq. Unsur-unsur lingual tersebut sebagai pembentuk struktur wacana wifiq.

\section{DAFTAR PUSTAKA}

Davies, Owen. 2009. Grimories : A History of Magic Books. New York: Oxford University Press

Djajasudarma, Fatimah.2012. Wacana dan Pragmatik. Bandung: Refika Aditama

Gardiner, Noah.2012. "Forbiden Knowledge? Notes On Production Transmisions And Reception Of The Major Work Of Ahmad Al Buni". Journal of Arabic And Islamic Studies 12 (2012)

Haliday dan Hasan. 1985. Language Context and Text of Social Semiotic Perspective. Melbourne : Deaklin University

Ibn Jinni, Abu Al Fath. 1957. Al Khașāiș. Jilid 1-3 Maktabah 'Ilmiah Wa Al Hikam

Kridalaksana, Harimurti.2008. Kamus Linguistik. Jakarta: Gramedia Pustaka Utama

Loekman, Wahidin. 2010. Makna Artefak Jimat Berbasis Aksara Arab Yang Bersimbol Semar Dan Macan Ali Di CirebonJawa Barat. Bandung: Disertasi

Muhdlor, Zuhdi. 1999. Kamus Kontemporer Arab Indonesia. Yogyakarta: Multi Karya Grafika 
Parera, J.D. Teori Semantik. Jakarta: Erlangga

Sugono, et al. 2008. Kamus Bahasa Indonesia. Jakarta Pusat Bahasa

Thurston,W.R.1987. Processes of change in the languages of north-western New Britain. In PacificLinguistics B99. Canberra: The Australian National University

Kaelan.2009. Filsafat Bahasa Semiotika dan Hermeneutika. Yogyakarta: Paradigma

Leech, Geofrey. 1983. Pragmatics. Cambridge. Cambridege University Press

Qosim, M. Nanang. 2014. "Analisis Wacana Pemilihan Ayat-ayat Alquran Untuk Pembuatan Jimat Dengan Pendekatan Makna". Jurnal Al Tsaqafa Adab dan Humaniora Vol 11 No. 1 Bandung: UIN Sunan Gunung Jati

Wittgenstein, Ludwig.1961. Tractus Logico-Philosophicus. London : Routledge \& Kegan paul L.T.D 
E Jurnal al-Tsaqafa Volume 13, No. 01, Januari 2016

Halaman sengaja untuk dikosongkan 